\title{
A Survey and Analysis of Mobile Learning of Local Undergraduate College Students*
}

\author{
Jiaosheng Qiu \\ Taishan University, China
}

\begin{abstract}
Mobile learning is a new learning mode with the increasing popularity of multimedia technology and Internet application. It not only emphasizes the learner's subjective status and initiative, but also helps learners construct meanings through various forms of interaction (Qiu,2019). This paper investigates the basic situation of students' mobile learning based on smart phones in local colleges and universities by means of questionnaire survey and interview. It also analyses the main problems and reasons of students' mobile learning based on smart phones in local colleges and universities, and explores relevant countermeasures and suggestions.
\end{abstract}

Index Terms — local undergraduate colleges, mobile learning, survey

\section{INTRODUCTION}

Since March 2015, when Premier Li Keqiang put forward the "Internet + " action plan at the third session of the Twelfth National People's Congress, "Internet +" has rapidly become a hot word. The mixed teaching mode and multi-element interactive learning environment supported by modern information technology, such as Internet and intelligent equipment, are the inevitable trend of foreign language education reform in Colleges and universities. (Zhai Shujie, 2017)

In the latest edition of College English Teaching Guidelines (2017) issued by the Ministry of Education, it is clearly pointed out that in the Internet era, the use of modern teaching methods should actively adapt to the learning characteristics and learning styles of college students in the new era, and pay close attention to the latest development of mobile learning theory. Conditional colleges and universities can design and construct "mobile English learning platform". Therefore, mobile learning is "mutual". The development direction of foreign language education in Colleges and universities in the era of Internet plus.

\section{Definition OF CORE CONCEPTS}

The "Wireless Andrew" research project launched in 1994 was the first mobile learning research project in the world. After the project was launched, the global mobile learning research project was launched. It was not until 2000 that mobile learning was introduced to China by Dr. Kiegen. After nearly ten years of research and development, China's mobile learning research has made unprecedented development. Mobile learning (M-Learning) is a new type of digital learning mode which combines the development of mobile technology and digital learning technology. In Europe and the United States, M-Learning or M-Education is generally referred to, and in China mobile learning or mobile education is generally described(Qiu,2019).

At present, there are different understandings about the definition of mobile learning from different perspectives, which can be roughly divided into three categories: first, mobile learning as a new form of distance education; second, mobile learning as an extension of e-learning; third, from the perspective of cognitive learning, mobile and situational characteristics of mobile learning make it a brand-new one. Technology and learning style. Mobile learning is a new form of learning that uses wireless mobile communication network technology and wireless mobile communication equipment (such as mobile phone, PDA, Pocket PC, etc.) to obtain educational information, educational resources and educational services. Compared with other forms of learning, mobile learning has the characteristics of convenient learning, individualized teaching, rich interaction and context relevance (Ye Chenglin et al., 2004). In Finland, mobile learning is defined as a new way of learning using mobile devices because of the increasing demand for geospatial mobility and flexible learning, which is co-sponsored by Erlcsson, Insite, Telenor Mobile and IT Fornebu Knowation (Qiu,2019).

To sum up, we can generalize the definition of mobile learning as follows: mobile learning is an extension of digital learning, which means that learners can obtain information, resources and carry out learning anytime and anywhere

\footnotetext{
* Fund projects: Shandong Social Sciences Planning Research Project “Analysis and Mechanism of College Students' English Mobile Learning Adaptation from the Perspective of Dynamic System Theory" (17CWZJ16), "A Study on the Development Model of College Freshmen's English Learning Adaptation from the Dynamic Perspective"(16CWZJ08); Shandong Education Science Planning Project “Application of Mobile Micro learning Based on Mobile Phone Terminal in College English Teaching" (BCGW2017011); Taishan University Teaching Reform Project "Research on the Reform and Practice of College English Teaching Guided by the Output-oriented Approach" (201846)
} 
with the help of miniaturized mobile computing devices and mobile interconnection technology (Qiu, 2019).

\section{REVIEW OF THE RESEARCH StATUS AT HOME AND ABROAD}

\section{A. Mobile Learning}

Mobile learning is a new learning mode with the increasing popularity of multimedia technology and Internet application. It not only emphasizes the learner's subjective status and initiative, but also helps learners construct meanings through various forms of interaction. In view of the important role of mobile learning for learners, the academic community has also discussed mobile learning of English. Domestic research on English mobile learning mainly focuses on the following five categories: the first is the theoretical model of English mobile learning, which involves the construction and exploration of mobile English teaching or learning mode. The second category is the research of mobile English learning technology, which mainly focuses on the design and development of mobile English learning system. The third category is the research on the construction of English mobile learning resources, including the design and application of mobile learning resource packages, and the exploration of the integration of information technology or assisted mobile digital learning resource system with English curriculum. The fourth category is the practical study of English mobile learning, which aims to focus on the application and Empirical Study of mobile learning in English language competence training, including the empirical study of English listening, speaking and writing teaching and the application of vocabulary learning. The fifth category is the survey of the current situation of English mobile learning, aiming at investigating and analyzing the current situation of college students' English mobile learning, putting forward improvement strategies to improve the efficiency of mobile learning, and providing reference for future research (Qiu, 2019).

The classification of English mobile learning research abroad is similar to that in China. It mainly involves the exploration of theoretical models or methods, the technical research of improving English vocabulary level and overall language level, the practical research of improving learners' English listening and writing skills and two or more skills, as well as the exploration of the use of English Mobile Learning strategies(Qiu,2019).

\section{B. Survey and Research on the Current Situation of Mobile Learning}

Wu Beibei (2012) conducts a questionnaire survey on College Students' mobile learning, statistics and analysis of the survey results, summarizes the current situation of College Students' mobile learning, and in-depth analysis of the problems and causes of mobile learning. Zhang Yumei (2012) analyzed the current situation of mobile learning of Yinchuan University students through questionnaires, aiming at understanding the mobile learning equipment, attitude and behavior that college students often adopt, in order to provide reference for the development of mobile learning system and learning resources(Qiu,2019). Tao Yao et al. (2012) selected five representative universities in Wuhan as the subjects of the survey. By means of questionnaires, interviews and other methods, based on the summary of the current situation of College Students' mobile learning using smart phones, the paper puts forward some pertinent suggestions and countermeasures. Deng Lijun et al. (2013) investigated and analyzed the use of resources, emotional attitudes, behaviors and needs of students in mobile learning in Jiangnan University by means of questionnaires, pointed out the problems existing in the process of College Students' mobile learning, and put forward their own opinions and suggestions on the development of mobile learning(Qiu,2019). Lujiang (2014) surveyed the types and performances of mobile learning devices used by current campus learners, the types and presentation forms of mobile learning resources that college students tend to use, the easily accepted mobile learning mode, the personalized needs of mobile learning situations, the learners' attention and persistence in mobile learning, and the attitudes and expectations towards mobile learning. This paper analyses the causes and solutions of the problems in mobile learning. Liu Minna (2014) used questionnaire and interview methods to investigate the basic situation of mobile learning of normal students based on smart phones, analyzed the main problems and reasons of mobile learning of normal students based on smart phones in local colleges and universities, and explored relevant countermeasures and suggestions. Lin Moujin and Huang Huibin (2014) analyzed the current situation of College Students' understanding of mobile learning, the conditions of mobile learning, the utilization of mobile learning resources, the selection of mobile learning content and the effect of mobile learning through a questionnaire survey of mobile learning among college students in Xiamen City. In view of the existing problems, some suggestions and strategies were put forward to improve the efficiency of mobile learning among college students. Yang Lin et al. (2014) surveyed and analyzed the current situation of mobile learning by using smart phones among college students in Gansu Province through statistical questionnaires, explored the needs and expectations of students for mobile learning, and put forward conclusions and suggestions for future research on mobile learning(Qiu,2019). Chen Ping (2014) analyzed the current situation of mobile English learning among students in Wuhan City Vocational College through questionnaires, aiming at understanding the understanding, interest, application, demand and learning obstacles of mobile English learning among higher vocational students, with a view to providing practical and credible data reference and guidance for the improvement of mobile English teaching and learning. Yang Liyuan and Li Jiawei (2015) focused on questionnaire survey, integrated literature analysis, statistical description and other research methods, selected Jiaying College students as the research object, investigated and analyzed the current situation of college students' English mobile learning, and put forward improvement strategies: attaching importance to the promotion of mobile learning, facing the role of mobile learning, setting learning goals scientifically, enhancing 
self-monitoring awareness, and benefit. Build a mobile learning platform with social tools(Qiu,2019).

It can be seen that in recent years, researchers at home and abroad have focused on a single theoretical model, technology and design research, resource construction, strategy use or practical application of mobile learning. Multidimensional comprehensive research on English mobile learning needs to be carried out. The Ten-Year Development Plan of Educational Informatization (2011-2020) issued by the Ministry of Education in 2012 indicates that higher education informatization is an effective way to promote higher education reform, innovation and quality improvement, as well as an innovative frontier in the development of educational informatization. It also proposes to promote the modernization of educational content, teaching means and methods by promoting the deep integration of information technology and education and teaching. No. 5. Mobile learning, with its advantages of mobility, wireless, portability and resource sharing, will not only fill the gap of traditional learning, but also become a new hotspot of educational informatization ((Qiu,2019, Huang Zhenyi, 2017). In view of this, the purpose of this paper is to carry out an investigation and Study on the current situation of mobile English learning in local undergraduate colleges and universities. The purpose of this study is to investigate and analyze the current situation of mobile English learning among college students, and put forward improvement strategies to improve the efficiency of mobile English learning, and to provide reference for future research.

\section{About The SuRVEY}

This research mainly adopts the methods of questionnaire survey, interview and descriptive statistical analysis, and makes use of the self-made questionnaire of mobile learning status of local undergraduate students based on smart phones to investigate the students of Taishan College, and carries out in-depth interviews with some students, in order to understand the factors affecting and restricting normal students' mobile learning based on smart phones. The questionnaire refers to Liu Minna's (2014) Questionnaire on the Current Situation of Mobile Learning for Normal Students Based on Smart phones, which is divided into two parts: The first part is the awareness of using smart phones to carry out mobile learning, because the consciousness state will determine the follow-up behavior of people engaged in certain things, so it is necessary to first understand that local undergraduate students use smart phones to open. Develop the awareness of mobile learning. The second part is the specific behavior of mobile learning using smart phones, including how to do and what to do, mainly investigating the ways and contents of students' access to resources through mobile learning.

A total of 425 questionnaires were collected and 24 invalid questionnaires were excluded. A total of 401 valid questionnaires were obtained. The questionnaires were sent to 500 normal students of different grades in liberal arts, science and engineering, such as Chinese language and literature, mathematics, bioengineering, history, museology, accounting, electronic information, musicology, mechanical engineering, etc. $24.4 \%$. The survey data were analyzed by SPSS16.0. The experimental results were obtained and the conclusions were summarized.

\section{QuestionnAire Results AND DataAnALYSis}

\section{A. Awareness of Local College Students' Mobile Learning Using Smart Phones}

As shown in Table 1, 357 students $(89.03 \%)$ said they knew "mobile learning", while only 9 students said they did not, accounting for only $2.24 \%$ of the total number. This result is quite unexpected, because in previous studies (Liu Minna, 2014), only $10.9 \%$ of students knew mobile learning and $69.6 \%$ of students did not know it. This shows that in recent two years, with the continuous improvement of mobile technology, local undergraduate students began to gradually understand mobile learning. But in contrast, in the second question, "whether to use smart phones for learning or access to learning materials", the proportion of students who often, occasionally, rarely and never use smart phones is $22.19 \%, 14.46 \%, 59.35 \%$ and $3.99 \%$, respectively. Especially, the proportion of students who seldom use smart phones for learning or access learning materials reaches an astonishing 59.35\%. That is to say, although students know that smart phones can be used for English learning, they still use them as a communication tool rather than a means of learning in real life. Among the questions of whether mobile learning is feasible or not, 30.17\% of the respondents think that mobile learning can be considered, $13.47 \%$ think that it can only be used as an assistant learning tool, and $52.62 \%$ think that mobile learning has a great development space. It shows that local college students are very optimistic about mobile learning based on smart phones. This is also quite different from previous studies (Liu Minna, 2014). Finally, $65.84 \%$ of the respondents expressed their willingness to use smart phones for mobile learning, $22.19 \%$ of the respondents expressed their willingness, and the ratio of the two was $88.03 \%$. It can be seen that most local undergraduate students expect mobile learning very much, which is consistent with the results of the previous question. 
TABLE 1

LOCAL COLlege STUdents' AwARENESS OF MOBILE LEARNING USING SMART PHONES

\begin{tabular}{|c|c|c|c|c|}
\hline Question & Option & Number & Proportion & $\mathrm{P}$ \\
\hline \multirow{3}{*}{$\begin{array}{l}\text { Do you know mobile } \\
\text { learning? }\end{array}$} & Yes, I know. & 357 & $89.03 \%$ & \multirow[t]{3}{*}{$<0.01$} \\
\hline & Yes, but it's very vague. & 35 & $8.73 \%$ & \\
\hline & No. & 9 & $2.24 \%$ & \\
\hline \multirow{4}{*}{$\begin{array}{l}\text { Have you ever used a smart } \\
\text { phone for learning or } \\
\text { consulting learning } \\
\text { materials? }\end{array}$} & Always & 89 & $22.19 \%$ & \multirow[t]{4}{*}{$<0.01$} \\
\hline & Sometimes & 58 & $14.46 \%$ & \\
\hline & Seldom & 238 & $59.35 \%$ & \\
\hline & Never & 16 & $3.99 \%$ & \\
\hline \multirow{4}{*}{$\begin{array}{l}\text { Do you think mobile } \\
\text { learning is feasible? }\end{array}$} & Yes. & 121 & $30.17 \%$ & \multirow[t]{4}{*}{$<0.01$} \\
\hline & $\begin{array}{l}\text { Can only be used as a } \\
\text { supplementary means }\end{array}$ & 54 & $13.47 \%$ & \\
\hline & $\begin{array}{l}\text { There is a lot of room for } \\
\text { development. }\end{array}$ & 211 & $52.62 \%$ & \\
\hline & Not at all. & 15 & $3.74 \%$ & \\
\hline \multirow{4}{*}{$\begin{array}{l}\text { Are you willing to use } \\
\text { mobile phones for mobile } \\
\text { learning? }\end{array}$} & Very willing & 264 & $65.84 \%$ & \multirow[t]{4}{*}{$<0.01$} \\
\hline & Could try & 89 & $22.19 \%$ & \\
\hline & Reluctant & 34 & $8.48 \%$ & \\
\hline & It is a waste of time. & 14 & $3.49 \%$ & \\
\hline
\end{tabular}

\section{B. Specific Behavior of Local College Students in Mobile Learning Based on Smartphones}

In the survey of mobile learning behavior of students in local colleges and Universities Based on smart phones, the results of the survey (see table 2) show that the author adds two questions on the basis of Liu Minna's questionnaire (2014). One is the proportion of students using mobile phones for leisure and entertainment, the other is the proportion of students discussing problems with their classmates through Wechat. The results of the questionnaire show that $74 \%$ of students have more than one day. The number of students who use mobile phones for recreation is less than one time a week and never use mobile phones is only one person, which indicates that the main function of most students' smartphones is communication and entertainment. Of course, we can also see that many times a day or once a day using mobile phones to discuss problems with classmates through voice, through Wechat to discuss problems with classmates, electronic dictionaries, notebooks and other items occupy a large proportion of students, especially to obtain the assignments and tasks assigned by teachers, the proportion of one time a day and many times a day is as high as $86 \%$, which shows that in classmates. At the same time, the majority of teachers have realized this trend, and gradually began to learn "mobile teaching". Few students discuss problems with their classmates through short message, which shows that the traditional function of short message on mobile phone is gradually replaced by communication APP such as Wechat. Of course, we should also see that the frequency of students doing such problems as listening to recorded courses, reading teacher's course notes and sending their questions to teachers after class is relatively low, which shows that there is little interaction between students and teachers, and most of them do so. It is a one-way connection, either students use mobile phones to take notes, or teachers assign homework, students passively accept, lack of communication links. Moreover, students seldom take the initiative to use mobile phones to learn, often in the completion of homework or encounter questions, new words and other situations is to play the mobile learning function of mobile phones, lack of initiative. 
TABLE 2

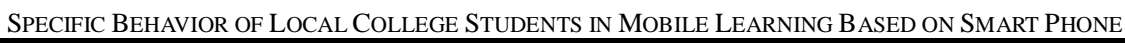

\begin{tabular}{|c|c|c|c|c|c|c|c|c|c|c|}
\hline \multirow[t]{2}{*}{ Question } & \multicolumn{2}{|c|}{$\begin{array}{l}\text { Many times } \\
\text { a day }\end{array}$} & \multicolumn{2}{|c|}{ Once a day } & \multicolumn{2}{|c|}{ Once a week } & \multicolumn{2}{|c|}{$\begin{array}{l}\text { Less than } \\
\text { once a week }\end{array}$} & \multicolumn{2}{|l|}{ Never } \\
\hline & Number & $\%$ & Number & $\%$ & Number & $\%$ & Number & $\%$ & Number & $\%$ \\
\hline Entertainment & 298 & $74 \%$ & 76 & $19 \%$ & 25 & $6 \%$ & 1 & $0 \%$ & 0 & $0 \%$ \\
\hline $\begin{array}{l}\text { Discuss with your classmates through } \\
\text { voice calls }\end{array}$ & 87 & $22 \%$ & 126 & $31 \%$ & 155 & $39 \%$ & 32 & $8 \%$ & 0 & $0 \%$ \\
\hline $\begin{array}{l}\text { Discuss problems with classmates } \\
\text { through short messages }\end{array}$ & 4 & $1 \%$ & 45 & $11 \%$ & 43 & $11 \%$ & 58 & $14 \%$ & 250 & $62 \%$ \\
\hline $\begin{array}{l}\text { Discuss with your classmates through } \\
\text { Wechat }\end{array}$ & 177 & $44 \%$ & 98 & $24 \%$ & 65 & $16 \%$ & 59 & $15 \%$ & 1 & $0 \%$ \\
\hline Electronic Dictionary Function & 201 & $50 \%$ & 55 & $14 \%$ & 76 & $19 \%$ & 60 & $15 \%$ & 8 & $2 \%$ \\
\hline Teaching Materials & 98 & $24 \%$ & 87 & $22 \%$ & 155 & $39 \%$ & 50 & $12 \%$ & 10 & $2 \%$ \\
\hline $\begin{array}{l}\text { Use spare time to listen to recorded } \\
\text { courses }\end{array}$ & 56 & $14 \%$ & 55 & $14 \%$ & 44 & $11 \%$ & 136 & $34 \%$ & 109 & $27 \%$ \\
\hline Notebook as Key Information & 185 & $46 \%$ & 98 & $24 \%$ & 76 & $19 \%$ & 22 & $5 \%$ & 19 & $5 \%$ \\
\hline Reading the teacher's Lecture Notes & 48 & $12 \%$ & 56 & $14 \%$ & 65 & $16 \%$ & 100 & $25 \%$ & 131 & $33 \%$ \\
\hline Reading or reading papers & 178 & $44 \%$ & 122 & $30 \%$ & 77 & $19 \%$ & 21 & $5 \%$ & 2 & $0 \%$ \\
\hline $\begin{array}{l}\text { Obtain assignments and tasks assigned } \\
\text { by teachers }\end{array}$ & 288 & $72 \%$ & 58 & $14 \%$ & 33 & $8 \%$ & 16 & $4 \%$ & 5 & $1 \%$ \\
\hline $\begin{array}{l}\text { Searching for Learning Materials on } \\
\text { the Internet }\end{array}$ & 121 & $30 \%$ & 87 & $22 \%$ & 67 & $17 \%$ & 97 & $24 \%$ & 28 & $7 \%$ \\
\hline Send your questions to the teacher & 33 & $8 \%$ & 57 & $14 \%$ & 98 & $24 \%$ & 101 & $25 \%$ & 111 & $28 \%$ \\
\hline $\begin{array}{l}\text { Sharing Learning Materials with } \\
\text { Students }\end{array}$ & 41 & $10 \%$ & 79 & $20 \%$ & 205 & $51 \%$ & 49 & $12 \%$ & 26 & $6 \%$ \\
\hline
\end{tabular}

\section{ANALYSIS}

From the survey results, with the progress of technology, the functions of smart phones are becoming more and more convenient. As a young people who are easy to accept new things, college students follow the trend of fashion and have a strong ability to accept and apply information tools. Therefore, the application of mobile phones is gradually penetrated into the learning process. In fact, they have adopted the way of mobile learning unconsciously. The exhibition of learning. Most of the respondents have some knowledge about mobile learning. In the actual application process, most of the learners have used smart phones to carry out mobile learning, and are confident about mobile learning. However, in real learning and life, mobile learning based on smart phones is only one of the many learning methods for students, and has not gained a dominant position. At this stage, mobile phones play more functions of communication and entertainment among local college students.

Through questionnaires, we found that local undergraduate students can use mobile phones to take notes, check teachers' homework, check new words, read books or papers, etc. They can also use Wechat software to discuss problems with their classmates through voice calls. This shows that although students know mobile learning, they do not realize that what they are doing is mobile learning, and there is little interaction between students and teachers, most of which are one-way links, either students use mobile phones to take notes, or teachers assign homework, students passively accept, lack of communication links. Moreover, students seldom take the initiative to use mobile phones to learn, often in the completion of homework or encounter questions, new words and other situations is to play the mobile learning function of mobile phones, lack of initiative. The mobile learning based on smart phones of local college students is emerging, but the initiative needs to be improved.

\section{CONCLUSION}

From a realistic point of view, with the impact of the trend of smart phone use, most normal school students have often used smart phones to carry out mobile learning, such as memorizing words, practicing listening, consulting knowledge and information, but learners do not really realize that their learning is mobile learning, there is no clear understanding of mobile learning, mobile learning methods and concepts are more. It is impossible to talk about it, which will lead to the majority of learning behavior is completed without planning and purpose. Passing time, passively completing tasks and consulting new words become the main motivation of mobile learning. Mobile learning has a certain foundation in local colleges and universities. We should strengthen students' awareness of using smart phones to carry out mobile learning and enhance their initiative to carry out mobile learning.

With the application of 4G, 5G network and smart phone technology becoming more and more mature, the network services of smart phones and operators become more and more commercialized. While mobile phone manufacturers and network operators make profits, they should pay more attention to the educational functions of mobile phones. Mobile learning based on smart phones has broad application prospects. Therefore, smart phone developers should attach importance to the mobile learning function. Develop and develop mobile learning-oriented smart phones to meet the needs of mobile learning groups in Colleges and universities. In addition, schools should carry out the construction of intelligent campus as soon as possible, reduce the cost of students' network use, and give some incentives for mobile 
learning activities by using mobile phones, so as to increase the initiative of students to carry out mobile learning.

Although the mobile learning of undergraduate students based on smart phones is still immature, and there are even big problems, with the continuous development and maturity of Internet 4G and 5G technology and the improvement of people's learning awareness, local colleges will keep pace with the times, constantly innovate the teaching and learning methods, and gradually realize and attach importance to smart phones as a learning society and lifelong learning. The convenience brought about by mobile learning based on smart phones will inevitably continue to develop and progress in the information society.

\section{REFERENCES}

[1] Chen Ping. (2014). Research on Mobile English Learning in Higher Vocational Colleges Based on Mobile Learning Terminals: Taking Wuhan City Vocational College as an example. Journal of Hubei Vocational and Technical College of Industry, 04,102-104.

[2] Deng Liejun, Yu Wentao, Chen Ling, Liu Xiaoying, Xu Xiaochen and Zhang Hongying. (2013). A Survey of Mobile Learning Status of College Students - Taking Jiangnan University as an Example. Electronic Technology and Software Engineering, 22, 29-31.

[3] Li Ting. (2017). Investigation and Countermeasure Research on the Current Situation of Mobile Learning of College Students. Master Dissertation, Central China Normal University.

[4] Lin Moujin, Huang Huibin. (2014). Investigation and Research on the Current Situation of Mobile Learning of College Students - Taking a University in Xiamen as an example. Journal of Jimei University (Educational Science Edition), 02, 20-24.

[5] Liu Minna. (2014). Investigation and analysis of mobile learning status of normal college students based on smartphones. Contemporary Education Science, 07, 28-32.

[6] Lujiang. (2014). Research on Mobile Learning of College Students Based on Smartphones. Master Dissertation, Shanxi Normal University.

[7] Qiu Jiaosheng. (2019). A Review of Mobile Learning Research at Home and Abroad in Recent 20 Years", Journal of Language Teaching and Research,05,1097-1102.

[8] Qiu Jiaosheng. (2019). A Preliminary Study of English Mobile Learning Model Based on Constructivism", Theory and Practice in Language Studies, 09, 1167-1172.

[9] Tao Yi, Zhang Guangze, Liu Xingxing, Zhao Yunyun. (2012). A study on the current situation of mobile learning among college students using smart phones --- Taking the survey of five universities in Wuhan as an example. Journal of Wuhan Metallurgical Management Cadre College, 03, 42-45.

[10] Wu Beibei. (2012). Survey and analysis of mobile learning status of college students. Master Dissertation, Shanghai Normal University.

[11] Yang Liyuan, Li Jiawei. (2015).Survey and analysis of the current situation of mobile English learning among college students. Software Guide (Educational Technology), 51-53.

[12] Yang Lin, Zhu Zhengping and Feng Jie. (2014). Investigation and analysis of mobile learning status of college students based on smartphones. Automation and instrumentation, 07, 202-205.

[13] Ye Chenglin, Xu Fuyin, Xu Jun. (2004). A Review of Mobile Learning. Research on Audiovisual Education, 03, 12-19.

[14] Zhai Shujie. (2017). Research on the current situation of Mobile English learning in Colleges and Universities under the background of "Internet +". Journal of Jining College, 05, 75-83.

[15] Zhang Yumei, Wang Xueming. (2012). Investigation and Research on the Current Situation of Mobile Learning of College Students. Computer Education, 05, 17-20.

Jiaosheng Qiu was born in Tengzhou, China in 1983. He received his master's degree in foreign linguistics and applied linguistics from Shandong Agricultural University, China in 2012.

He is currently a lecturer in the Department of College Foreign Languages Teaching, Taishan University, Tai'an, China. His research interests include Second Language Acquisition and College English Teaching. 